\title{
SELECTED EUROPEAN UNION OPERATIONAL FUNDS' IMPACT ON NEWLY EMERGING SMES IN THE LUBELSKIE VOIVODESHIP
}

\author{
Katarzyna Boratynska" ${ }^{1,} \mathrm{PhD}$.; Emilia Andrusiewicz ${ }^{21} \mathrm{MSc}$ \\ ${ }^{1}$ Warsaw University of Life Sciences - SGGW, Faculty of Economic Sciences, Department of Finance; \\ ${ }^{2}$ Business Activity: EMILIA ANDRUSIEWICZ
}

\begin{abstract}
The research problems comprise issues connected with acquiring EU funds for newly established SMEs. The main purpose of the article is to discuss the significance of the EU funds for the establishment of SMEs in the Lubelskie Voivodeship. The research included the following tasks: characterization of selected aid funds, description and assessment of instruments that support the development of the newly established small and medium-sized enterprises as well as presentation of advantages that stem from the implementation of the aid funds in the Lubelskie Voivodeship. In order to meet the aim of the article and to verify the hypotheses elements of statistics, descriptive and tabular analysis were also used. A case study method was also applied. The theoretical part of the paper describes the SME sector and its role in the economy. The empirical part analyses the Regional Operational Program for the Lubelskie Voivodeship, as well as a total of 20 projects implemented under the Human Capital Operational Programme and addressed for the newly established SMEs. However, the article is limited only to presenting the details of 4 selected projects taking the criterion of the highest amount of the acquired funds into account. As a result, entrepreneurs have a chance of obtaining funds allowing them to establish and develop their businesses. Due to the use of the aid funds, many new jobs were created, which had a positive impact on a decrease in unemployment, as well as on the local development. For instance, the Human Capital Operational Programme, Priority VI, Operation 6.1, co-financed by the EU under the European Social Fund for 2007-2013 in the Lubelskie Voivodeship provided as much as over PLN 354 million, with the EU funding amounting to over PLN 299 million. As a result of those funds, 5.109 new businesses were opened. An important result was also an increase in entrepreneurial awareness and conducting own business activity, which in the future can stimulate further economic growth of the Lubelskie Voivodeship.
\end{abstract}

Key words: European Union operational funds, small and medium-sized enterprises.

JEL code: F15, F35, F36, F63

\section{Introduction}

The small and medium-sized enterprise sector (SME) in Poland has a significant impact on the employment level and economic growth of particular regions, as well as the entire country. Small and medium-sized enterprises create new jobs. A major obstacle in the development of small and medium-sized enterprises is the problem with obtaining funds at the initial stage of commencing business activity. Lack of financial resources prevents investments and, furthermore, the enterprise is not competitive, which leads to bankruptcy in the first year of conducting business activity. In Poland, that percentage value is approximately 26 \% (Raport o stanie sektora..., 2015, p. 36).

Poland is a beneficiary of EU funds received under particular financial perspectives. The main goal of these is to reduce disparities between levels of development of the other EU countries (Sikora-Gaca M., Kosowska U., 2014, p. 13). The European Union strives to create a knowledgebased competitive economy. One of the focus areas of assistance under the EU funds is stimulating and supporting entrepreneurship in particular countries and regions. Through the investments in the human capital and development of innovation the EU implements its joint strategy to establish efficient economy. The small and medium-sized enterprise sector contributes to sustainable growth of the entire country. Small and medium-sized companies also improve innovativeness of the Polish economy as well as mitigate the negative effects of economic crises.

\section{Methodology of the study}

The Lubelskie Voivodeship, constituting the area of empirical research, is a poorly developed voivodeship. The development of the small and medium-sized enterprise sector is a chance to 
strengthen its position. However, there are just a few studies connected with the use of the EU funds by newly established SMEs in the Lubelskie Voivodeship. Thus, the topic should be further studied. Another important issue is the assessment of the use of EU funds from the 2007-2013 perspective by people opening their own businesses.

The main purpose of the research was to assess the importance of the selected aid funds in the period of 2007-2013 (the research period was adopted in line with the EU financing perspective) in reference to the establishment of small and medium-sized enterprises (SMEs) in the Lubelskie Voivodeship. Under the formulated research goal, the following research tasks were selected:

- description of selected aid funds,

- characterisation and assessment of instruments supporting the development of the newly established small and medium-sized enterprises in the Lubelskie Voivodeship,

- presentation of advantages that stem from the implementation of the aid funds in the Lubelskie Voivodeship.

The article attempts to verify the following research hypothesis: the EU aid funds provide significant financial support for the establishment of new small and medium-sized enterprises, they reduce the unemployment rate and have a positive impact on the growth of the Lubelskie Voivodeship.

The empirical part of the research analyses the Regional Operational Programme for the Lubelskie Voivodeship, as well as a total of 20 projects implemented under the Human Capital Operational Programme in the Lubelskie Voivodeship addressed to newly established SMEs. The article is limited only to presenting the details of 4 selected projects supporting the newly established SMEs in the Lubelskie Voivodeship taking the criterion of the highest amount of the acquired funds into account ( 2 projects under the Human Capital Operational Programme, Priority VI "The labour market for everyone", Operation 6.1 "The improvement of access to employment and support for professional activity in the region" and 2 projects under the Human Capital Operational Programme, Priority VI "The labour market for everyone", Operation 6.2 "Support and promotion of entrepreneurship and self-employment").

\section{Research methods}

Data collection methods

The basic source of information on the importance of the EU aid funds for small and mediumsized enterprises in the Lubelskie Voivodeship was the data from: The Database of the National Information System SIMIK 07-13, materials made available by the Poviat Labour Offices, the Central Statistical Office, the Polish Agency of Entrepreneurship Development, reference books, and press articles.

\section{Data processing methods}

The article mostly analyses the data and information from secondary sources. In order to meet the goal of the paper and to verify the hypotheses elements of statistics, descriptive and tabular analysis were also used. A case study method was also presented.

Methods of result presentation

The research results and the presentation of the collected materials were presented with the use of: the graphical method, the descriptive and tabular method, as well as the analytical method.

\section{Research results and discussion}

\section{The role of small and medium-sized enterprises in the economy}


The term "small and medium-sized enterprise" was also defined based on the quantitative criterion (Table 1). It shows the size of the enterprise with the use of measurable parameters in the context of expenditure on its activity or the effects of the conducted activity (Lachiewicz S., Matejun M., 2012, p. 15).

Quantitative and qualitative criteria of classification of SMEs

Table 1

\begin{tabular}{|l|l|l|l|}
\hline \multicolumn{1}{|c|}{$\begin{array}{c}\text { Specification of } \\
\text { enterprises }\end{array}$} & \multicolumn{1}{|c|}{$\begin{array}{c}\text { Number of } \\
\text { employees }\end{array}$} & \multicolumn{1}{|c|}{ Annual turnover } & \multicolumn{1}{|c|}{ Total balance sheet } \\
\hline Micro & below10 employees & below $2 \mathrm{mln}$ euro & below $2 \mathrm{mln}$ euro \\
\hline Small & $10-49$ employees & $2-10 \mathrm{mln}$ euro & $2-10 \mathrm{~m} / \mathrm{n}$ euro \\
\hline Medium & $50-249$ employees & $10-50 \mathrm{~m} / \mathrm{n}$ euro & $10-43 \mathrm{mln}$ euro \\
\hline
\end{tabular}

Source: authors' study based on Nowa definicja MSP. Poradnik dla uzytkownikow i wzor oswiadczenia (New definition of SMEs. Guide for users and pattern of declaration)(2016), Wspolnoty Europejskie, p. 14

"In 2013, there were 1.77 million non-financial enterprises defined as active enterprises. Small and medium-sized enterprises constituted as many as $99.8 \%$ of those entities" (Raport o stanie sektora..., 2015, p. 13). The role of SMEs is shown in the data presenting the share of those companies in the creation of the Gross Domestic Product. Those enterprises generate $73 \%$ of the Gross Domestic Product. The small and medium-sized enterprise sector creates $48.5 \%$ of the GDP, with approximately $30 \%$ created by micro-enterprises (data for 2012) (Raport o stanie sektora..., 2015 , p. 13). In the research period, an increased share of small and medium-sized enterprise sector in the creation of the Gross Domestic Product is noticeable. The growth trends of mediumsized and large enterprises in the creation of the general value of the GDP should also be noticed.

Another important area showing the importance of SMEs for economic growth is the employment level in the sector. It should be noticed that during the researched period the small and medium-sized enterprise sector employed the greatest number of people. At the end of 2013, the number of people employed in Polish enterprises was almost 8.9 million, while $69.46 \%$ worked in the small and medium-sized enterprise sector. It should also be noted that the enterprises that employ more than 10 people have the greatest share in employment in the SME sector (in 2013 they constituted $54.53 \%$ of total employment in the SME sector and $37.88 \%$ in the total number of people employed by enterprises).

The number of enterprises in the Lubelskie Voivodeship in 2013 constituted only $4.17 \%$ of the total number of enterprises in Poland. In 2013, the SME sector constituted $99.89 \%$ of all enterprises registered in this voivodeship. Micro-enterprises constituted $95.79 \%$ of the total SME sector. A similar situation was observed in preceding years.

The main factors having impact on such a high percentage of micro-enterprises in the Lubelskie Voivodeship included: lack of work, problems with employment, hope of getting a better salary, the wish to improve one's own economic status, as well as the willingness to try self-employment (Wojewodzki Urzad Pracy w Lublinie, 2013, p. 13).

From 2007, the number of enterprises in the Lubelskie Voivodeship was decreasing. In 2010, this trend reversed, but the level of 2007 has not been achieved yet. However, an upward trend for the enterprises employing between 10 to 49 people should be noted. This may indicate the growth of micro-enterprises that started employing more people and, thus, transformed into small enterprises. In 2007-2013, the sector of small and medium-sized enterprises employed approximately $75-80 \%$ of all people employed in non-financial enterprises in the Lubelskie Voivodeship. Those enterprises generated the highest number of jobs. 
The importance and impact of the selected EU operational programmes to the establishment of small and medium-sized enterprises in the Lubelskie Voivodeship

\section{Regional Operational Programme for the Lubelskie Voivodeship}

The Regional Operational Programme for the Lubelskie Voivodeship is one of 16 regional operational programmes. The main purpose of the ROP LV is to "enhance the competitiveness of the Lublin Region to lead to accelerated economic growth and an increase in employment, taking the natural and cultural resources of the region into account" (Zarzad Wojewodztwa Lubelskiego, 2017, p. 5). The assumption of the Regional Operational Programme for the Lubelskie Voivodeship was to stimulate economic growth in less developed areas (Regionalny Program Operacyjny..., 2013, p. 90). In the 2007-2013 perspective, approximately EUR 1.192 .8 million from the European Regional Development Fund was allocated to implement the Regional Operational Programme for the Lubelskie Voivodeship (Regionalny Program Operacyjny..., 2013, p. 167).

Under the Regional Operational Programme for the Lubelskie Voivodeship, nine priority axes were identified: Entrepreneurship and innovation, Economic infrastructure, Attractiveness of urban areas and investment areas, the Information society, Transport, Environment and clean energy, Culture, tourism and inter-regional co-operation, Social infrastructure, Technical support (Regionalny Program Operacyjny..., 2013, pp. 111-164).

The Figure 1 shows the distribution of resources allocated for financing each of the nine priority axes mentioned above.

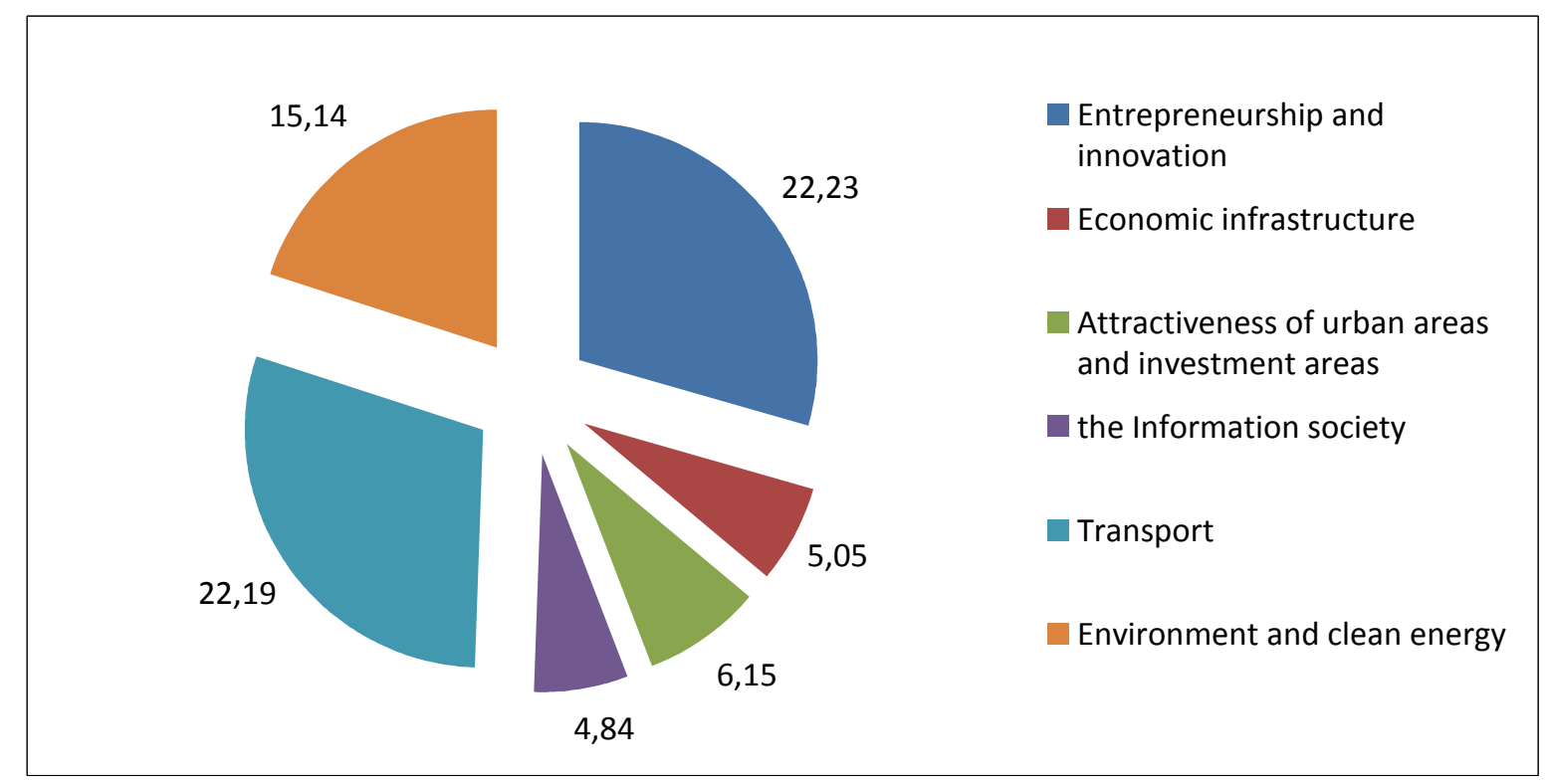

Source: Authors' calculations based on Regionalny Program Operacyjny Wojewodztwa Lubelskiego na lata 20072013 (Regional Operational Programme for the Lubelskie Voivodeship in 2007-2013) (2013). CCI

2007PL161P0007, Dokument przyjety przez Komisje Europejska w dniu 27 czerwca 2013 r., $111-164$.

Fig. 1. Percentage share of the structural funds under the Regional Operational Programme for the Lubelskie Voivodeship in reference to particular priorities

Subsidies for newly established micro-enterprises under the Regional Operational Programme for the Lubelskie Voivodeship

Due to the projects co-financed from the EU funds under the European Regional Development Fund - ROP LV under the priority I axis: Entrepreneurship and innovation, Operation 1.1. "Subsidies for newly established micro-enterprises in the Lubelskie Voivodeship", in 2008, 22 newly created micro-enterprises received subsidies. The total value of the projects awarded in 2008 was 
PLN 8.9 million and the EU co-funding amounted to PLN 3.9 million. In 2013, due to this financial support 50 Beneficiaries from the Lubelskie Voivodeship received subsidies. The total value of the projects under grant schemes for newly created micro-enterprises in 2013 was PLN 23.7 million and the EU co-funding amounted to PLN 8.7 million. In 2014, the subsidies for newly established micro-enterprises were used by 26 enterprises from the Lubelskie Voivodeship. The total value of the projects under this operation was PLN 10.2 million and the EU co-funding amounted to PLN 4.2 million (Lista beneficjentow Funduszy, 2017).

\section{The Human Capital Operational Programme as the source of financing the newly established SMEs in the Lubelskie Voivodeship}

The Human Capital Operational Programme (HCOP) was prepared in line with the Regulation of the Council (EC) no. 1083/2006 laying down general provisions on the European Regional Development Fund, the European Social Fund and the Cohesion Fund (Szczegołowy opis priorytetow, 2014, p. 6). The aim of the Human Capital Operational Programme is to encourage use of the potential of human resources by increasing employment, as well as taking advantage of the adaptive possibilities of employees and enterprises. The activities under the programme focused on increasing the education level, as well as reducing areas of social exclusion (Wecławski J., Misterek W., 2011). The Human Capital Operational Programme focused on supporting employment by activation of the unemployed. An important element of the programme was also supporting projects promoting entrepreneurship and self-employment. Those activities were aimed at increasing the potential of both employees and enterprises to enable further growth of those enterprises.

Under the Human Capital Operational Programme, Priority VI "The labour market for everyone", financed from the resources of the Labour Fund, projects allowing entities to receive support in the form of one-off funds to commence business activity, as well as support in the form of consultancy connected with commencing business activity were implemented in the Lubelskie Voivodeship.

The "Active on the labour market" project was implemented under the Human Capital Operational Programme, Priority VI "The labour market for everyone", Operation 6.1 "The improvement of access to employment and support for professional activity in the region". The beneficiary of the project was Poviat Chelmski - the Poviat Labour Office in Chelm. The project was implemented from 1 January 2008 until 31 December 2014. The project granted support for 6.691 people. The funds to commence own business activity were received by 615 people. Also support connected with reimbursement of the costs incurred for equipment and providing equipment to workplaces for 129 micro-enterprises, 31 small enterprises and 4 medium-sized enterprises was granted (Projekt "Aktywni na rynku pracy", 2008-2014, Powiatowy Urzad Pracy w Chelmie). The total value of the projects was PLN 50.7 million and the EU co-funding amounted to PLN 43.1 million (Lista beneficjentow Funduszy, 2017).

Another project under Sub-Operation 6.1.3. "Improvement of abilities of employing and increasing the level of economic activity of the unemployed" was the project called "Ambitious and entrepreneurial." The beneficiary of the project was Gmina Lublin - the City Labour Office in Lublin. The project was implemented from 1 January 2008 until 31 December 2014. The systemic project covered 2243 people. As a result of the financial support 575 participants commenced their own business activity (Projekt „Aktywni na rynku pracy”, 2008-2014, Miejski Urzad Pracy w Lublinie). 
The total value of the projects was PLN 59.1 million and the EU co-funding amounted to PLN 50.2 million (Lista beneficjentow Funduszy, 2017).

One of the projects implemented in the Lubelskie Voivodeship was "Be active - become an entrepreneur". The project was implemented under the Human Capital Operational Programme, Priority VI "The labour market for everyone", Operation 6.2 "Support and promotion of entrepreneurship and self-employment", based on the co-financing agreement for implementation of the project signed with the Voivodeship Labour Office in Lublin. The project was co-financed by the EU under the European Social Fund. The beneficiary of the "Be active - become an entrepreneur" project was Lubelska Szkola Biznesu Sp. z o.o. The main aim of the project was to grant assistance to natural persons intending to conduct business activity. The program was addressed to a group of 96 people with at least $70 \%$ of women participants. People living in rural areas constituted at least $30 \%$ of the group and people who lost work not due to their own fault constituted at least $10 \%$. The support under the project included free training and consultancy services for 96 people, financial means for the development of entrepreneurship - 70 subsidies up to PLN 40,000 and bridge support in the form of free specialist consultancy services and financial means paid out to 32 entrepreneurs for 6 months in monthly instalments whose amount did not exceed the amount of minimum wage. The project was implemented from 1 January 2010 until 30 June 2012. The total value of the projects was PLN 4.1 million and the EU co-funding amounted to PLN 3.5 million (Lista beneficjentow Funduszy, 2017).

An important project implemented under the Human Capital Operational Programme, Priority VI "The labour market for everyone", Operation 6.2 "Support and promotion of entrepreneurship and self-employment", based on the co-financing agreement for implementation of the project signed with the Voivodeship Labour Office in Lublin was the "Spread your wings!" project. The project was co-financed by the EU under the European Social Fund. The beneficiary of the project was Consultor Sp. z o.o. The main objective of the project was to increase the entrepreneurship level in the Lubelskie Voivodeship by supporting people opening new businesses. The participants of the project were 60 people, including 42 women and 18 men. The participants were unemployed and had not conducted their own business activity in the period of 12 months before the date of signing up to the project. Under support also financial means for the development of entrepreneurship was granted for 51 people, with the maximum amount of subsidy being PLN 40.000. Under the bridge support all entrepreneurs received financial support amounting to PLN 900 for the period of the first 6 months. 15 people, who had the greatest difficulty in conducting business activities, received prolonged bridge support of PLN 900 for the period of another 6 months. The project was implemented from 1 October 2010 until 31 May 2012. The total value of the projects was PLN 2.9 million and the EU co-funding amounted to PLN 2.4 million (Lista beneficjentow Funduszy, 2017).

\section{Conclusions, proposals, recommendations}

1) The small and medium-sized enterprise sector has a positive impact on economic growth both on the domestic and regional level. SMEs contribute to a reduction in unemployment on local markets. They also have influence on entrepreneurial attitudes and, thus, an increase in the wealth of the society in a given region. SMEs also have an impact on the regional development by using local resources, attracting investors and using aid programmes available for companies and regions. Small and medium-sized enterprises are also a source of taxes for the local 
budget. The SME sector is one of the key factors for increasing competitiveness in voivodeships and accelerating the pace of their economic growth.

2) Due to the projects co-financed from the EU funds under the European Regional Development Fund - the Regional Operational Programme for the Lubelskie Voivodeship under the priority I axis: Entrepreneurship and innovation, Operation 1.1. subsidies for newly established microenterprises under the 2007-2013 perspective in the Lubelskie Voivodeship were granted to a total of 402 newly created enterprises. The total value of all implemented projects was PLN 197.2 million and the EU co-funding amounted to PLN 72.5 million. The subsidies granted were to increase the investment predispositions at the initial phase of micro-enterprise operation. The preferred projects included innovative solutions which would have impacted the pace of growth of a given enterprise. All activities of the newly created enterprises should be aimed towards increasing competitiveness on the market, which was possible due to the means acquired from the EU funds.

3) Under the Human Capital Operational Programme, Priority VI "The labour market for everyone", Operation 6.1 "The improvement of access to employment and support for professional activity in the region", co-financed by the EU under the European Social Fund for 2007-2013 in the Lubelskie Voivodeship as much as PLN 354.1 million was allocated across the Lubelskie Voivodeship, with the EU funding amounting to PLN 299.9 million. As a result of those funds, 5.109 new businesses were opened. An important result was also an increase in the entrepreneurial awareness and conducting own business activity which, in the future, can stimulate economic growth of the Lubelskie Voivodeship.

4) Under the Human Capital Operational Programme, Priority VI "The labour market for everyone", Operation 6.2 "Support and promotion of entrepreneurship and self-employment", co-financed by the EU under the European Social Fund for 2007-2013, as much as PLN 23.0 million was allocated across the Lubelskie Voivodeship, with the EU funding amounting to PLN 19.3 million. As a result, as many as 331 new companies and 11 social cooperatives were established. From the researched group of people who commenced their own business activity, as many as 361 received bridge support which facilitated them entering the market as entrepreneurs.

\section{Bibliography}

1. Lachiewicz, S., Matejun, M. (2012). Specyfika zarzadzania malymi i srednimi przedsiebiorstwami. [W:] Zarzadzanie mała i srednia firma w teorii i cwiczeniach (The Specificity of Small and Medium Enterprises Management. [In:] A Small and Medium Company Management in Theory and Practice). Difin, p. 15.

2. Lista beneficjentow Funduszy Europejskich 2007-2013 - stan na 31 marca 2017 (List of EU Funds Beneficiaries in the Period of 2007-2013 - State of 31th March 2017) (2017). Baza Krajowego Systemu Informatycznego SIMIK 2007-2013.

3. Nowa definicja MSP. Poradnik dla uzytkownikow i wzor oswiadczenia (New definition of SMEs. Guide for users and pattern of declaration)(2016) Wspolnoty Europejskie, p. 14.

4. Projekt "Aktywni na rynku pracy" ("Active on the Labour Market" Project). Dane z lat 2008-2014. Miejski Urzad Pracy w Lublinie.

5. Projekt "Aktywni na rynku pracy" ("Active on the Labour Market" Project). Dane z lat 2008-2014. Powiatowy Urzad Pracy w Chelmie.

6. Raport o stanie sektora malych i srednich przedsiebiorstw w Polsce (State of Small and Medium-Sized Enterprises Sector Report) (2016). Polska Agencja Rozwoju Przedsiebiorczosci, Warszawa, p. 36.

7. Raport o stanie sektora malych i srednich przedsiebiorstw w Polsce $w$ latach 2013-2014 (State of Small and Medium-Sized Enterprises Sector Report in the period of 2013-2014) (2015). Polska Agencja Rozwoju Przedsiebiorczosci, Warszawa, p. 13.

8. Regionalny Program Operacyjny Wojewodztwa Lubelskiego na lata 2007-2013 (Regional Operational Programme for the Lubelskie Voivodeship in 2007-2013) (2013). CCI 2007PL161PO007, Dokument przyjety przez Komisje Europejska w dniu 27 czerwca 2013 r., pp. 90, 111-164, 167. 
9. Sikora-Gaca, M., Kosowska, U. (2014). Fundusze europejskie w teorii i praktyce. Edukacja, gospodarka, kultura, spoleczenstwo (EU Funds in Theory and Practice. Education, Economy, Culture, Society). Difin, Warszawa, p. 13.

10. Szczegolowy Opis Osi Priorytetowych Regionalnego Programu Operacyjnego Wojewodztwa Lubelskiego na lata 2007-2013 (Detailed Description of Priorities Axes of Regional Operational Programme for the Lubelskie Voivodeship in 2007-2013). Uszczegolowienie Programu Narodowe Strategiczne Ramy Odniesienia 20072013 Polska (National Strategic Framework Programme in 2007-2013 Details - Poland). Zarzad Wojewodztwa Lubelskiego, p. 5.

11. Szczególowy opis priorytetow Programu Operacyjnego Kapital Ludzki 2007-2013 (Detailed Description of Priorities of Human Capital Operational Programme in 2007-2013) (2014), Narodowa Strategia Spojnosci (National Cohesion Strategy), Warszawa, p. 6.

12. Weclawski, J., Misterek W. (red.), (2011). Uwarunkowania wykorzystania funduszy Unii Europejskiej przez jednostki samorzadu terytorialnego $w$ wojewodztwie lubelskim (Conditions of Using of EU Funds by local government in Lubelskie Voivodeship). Difin, Warszawa. 